\title{
INTRANODAL LYMPHANGIOMYOMATOSIS
}

D. Prem Charles ${ }^{1}$, Divvya B², Rehana Tippoo ${ }^{3}$, P. Viswanathan ${ }^{4}$, Gopikrishna ${ }^{5}$

\section{HOW TO CITE THIS ARTICLE:}

D. Prem Charles, Divvya B, Rehana Tippoo, P. Viswanathan, Gopikrishna. "Intranodal Lymphangiomyomatosis". Journal of Evolution of Medical and Dental Sciences 2014; Vol. 3, Issue 17, April 28; Page: 4683-4687, DOI: $10.14260 /$ jemds/2014/2496

ABSTRACT: Lymphangiomyomatosis is a malformative or hamartomatous proliferation of lymphatic channels and smooth muscles. A 32 year old male presented to RMMCH Annamalai University with pain and swelling over the suboccipital region. Routine investigations and chest x-ray were found to be normal. Histopathology revealed vascular spaces surrounded by smooth muscle cells. We here with present a case of intra nodal Lymphangiomyomatosis, which not only is an uncommon occurrence but also needs a regular follow up because of progressive involvement of the lungs, often resulting in death from pulmonary insufficiency within ten years.

KEYWORDS: Non hematolymphoid neoplasm, pulmonary insufficiency, smooth muscle like cells.

INTRODUCTION: Lymphangiomyomatosis (LAM) is a non-hematolymphoid neoplasm in which abnormal smooth muscle-like cells proliferate in the lungs and along the axial lymphatic systems, including the lymph nodes and thoracic ducts. These cells are transformed due to loss-of-function type mutations of either the TSC1 or TSC2 tumor suppressor genes. The pathological features include the proliferation of benign-looking LAM cells and the existence of abundant lymphatic vessels that are associated with clinical conditions such as chyle leakage. LAM cells produce potent lymphangiogenic growth factors (VEGF-C and VEGF-D) and the lymphatic vessel density within LAM lesions correlates with the histologic severity of LAM.

The serum VEGF-D level increases in LAM, especially in patients with lymphatic involvement. LAM cell clusters (LCCs), which are postulated pathologically to be generated by lymphangiogenesismediated fragmentation and subsequent shedding into the lymphatic circulation, are observed in both chylous effusion and LAM-associated lymphatics within LAM tissue specimens. The identification of LCCs in chylous effusion together with the characteristic clinical manifestations can therefore be an alternative for a lung biopsy if LAM patients are complicated with chylous effusion.

CASE REPORT: A 32 year old male developed pain and swelling over the suboccipital region for short duration of about a month and the swelling was gradual in onset and not associated with fever, loss of weight and appetite. On local examination the swelling was firm, not tender and no other swellings were noticed. Respiratory system examination reveals no associated deformities. Chest x-ray was found to be normal. Patient did not have any neurological deficit or any tell-tale sign of tuberous sclerosis.

Biopsy was done and sent for Histopathological examination.

Macroscopy revealed single grey yellow tissue piece measuring $1 \times 0.5 \times 0.5 \mathrm{~cm}$.

Microscopy showed lymph nodal tissue whose architecture was almost totally effaced (FIG:1) with original architecture retained only at the periphery(FIG:2) close to the capsule; there were several vascular spaces lined by endothelial cells. Some of the vessels had thickened walls; lymphoid 


\section{CASE REPORT}

aggregates (FIG: 5 \& FIG:6) and scattered inflammatory infiltrate (FIG: 9 \& 10) was seen between the tumor. Areas of edema were also seen.

Histological features were consistent with the diagnosis of lymphangiomyomatosis.

DISCUSSION: Lymphangiomyomatosis commonly affects women during reproductive years. ${ }^{1}$ Sometimes associated at times with pulmonary involvement, angiomyolipoma and tuberous sclerosis. ${ }^{2}$ Lung involvement often causes death from pulmonary insufficiency. ${ }^{3}$ Rarely it is an isolated finding in intra-abdominal lymph nodes. ${ }^{4}$ The thoracic duct, mediastinum, retroperitoneum, and lymph nodes (thoracic, axillary, cervical or intraabdominal) can also be involved.

Grossly, the lymph nodes are spongy, resilient, and pale tan or white. They are involved in a sinusoidal or more extensive fashion. The smooth muscle cells form short fascicles around an anastomosing network of endothelium lined spaces (FIG: 3 \& FIG: 7), resulting in a pericytomatous pattern. They are morphologically distinctive, with elongated spindle shape (FIG: 4 \& FIG 8) and regular oval nuclei with no atypia or mitoses. The cytoplasm is lightly eosinophilic to clear. Besides staining for various myogenic markers such as muscle specific actin and desmin, the smooth muscle stain consistently with HMB- 45.5

Lymphangiomyomatosis must be distinguished from metastatic well-differentiated leiomyosarcoma. The latter has no consistent relationship with the vascular channels; often shows greater cellularity, atypia, some mitotic figures, and more eosinophilic staining cytoplasm; and lacks HMB-45 immunoreactivity. ${ }^{2}$

\section{REFERENCES:}

1. Cornog JL, Enterline HT. Lymphangiomyoma, a benign lesion of chyliferous lymphatics synonymous with lymphangiopericytoma. Cancer 1966; 19:1909-30.

2. Enzinger FM, Weiss SW. Soft tissue tumors. $2^{\text {nd }}$ ed. St. Louis: CV Mosby, 1988:627-35.

3. Corrin B, Liebow AA, Friedman PJ. Pulmonary Lymphangiomyomatosis. Am J Pathol 1975; 79: 348-82.

4. Magrini U, Rosso R, Paulli M, et al. Solitary nodal Lymphangiomyoma: incidental findings in pelvic lymph nodes [Abstract]. Mod Pathol 1992; 5: 82A.

5. Tsang WY, Pau MY, Tang MC, Pang SW, Fletcher CD. Lymphangiomyomatosis and angiomyolipoma: closely related entities characterized by hamartomatous proliferation of HMB-45 positive smooth muscle. Histopathology 1993;2: 445-55. 


\section{CASE REPORT}

\section{MICROSCOPIC PICTURES - H\&E SECTIONS:}

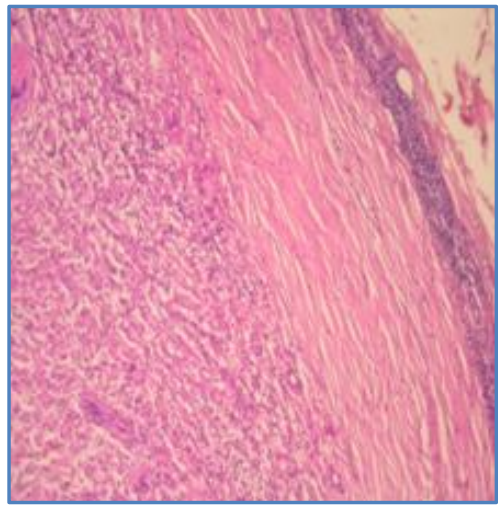

Fig. 1 :10X Lymph node architecture is effaced remnants of lymphoid tissue near capsule

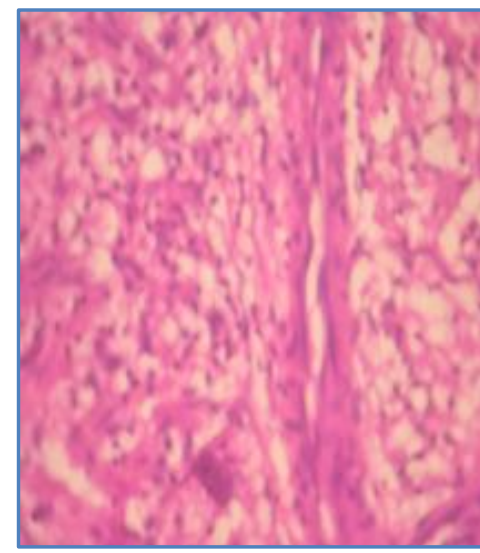

Fig. 3: 20X vascular channels surrounded by spindle shaped cells entire tissue is edematous

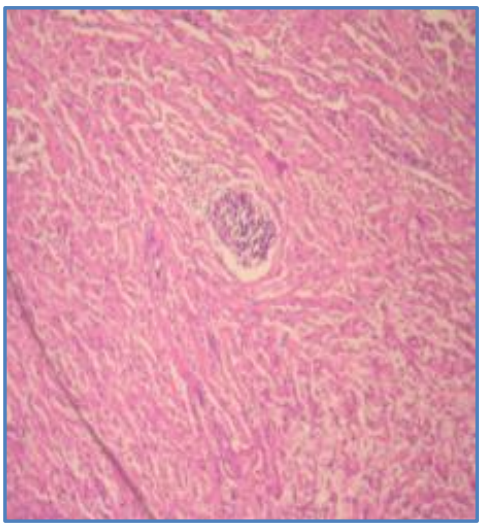

Fig. 5: 10X

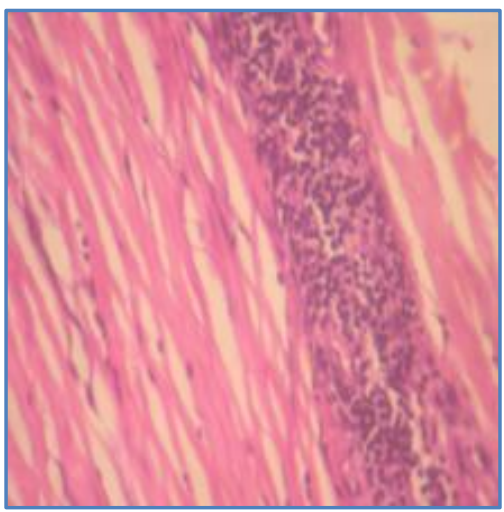

Fig. 2: 20X Lymphoid tissue is highlighted

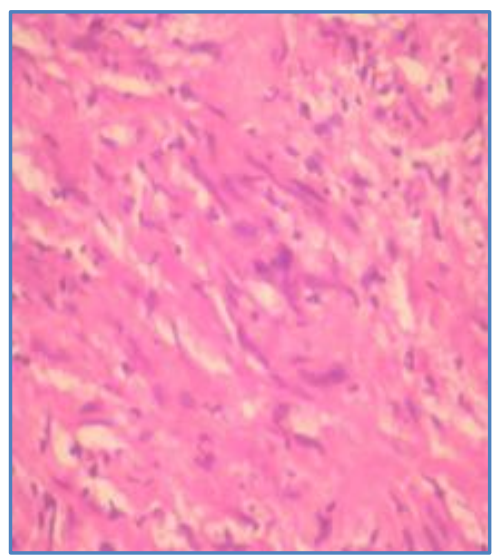

Fig. 4: 20X Elongated spindle shaped cells elongated nuclei, thin cytoplasm

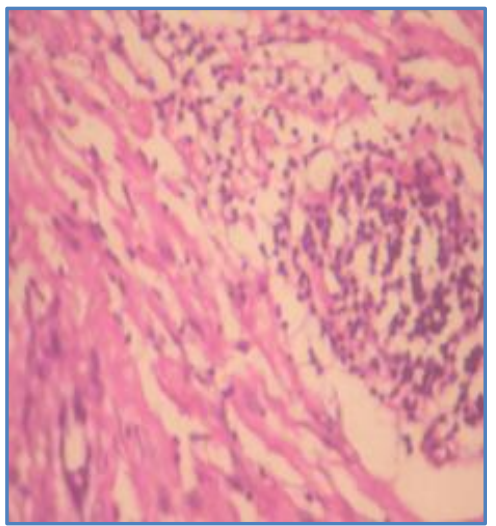

Fig. 6: 20X

Aggregates of Lymphoid tissue surrounded by Lymphangiomyoma. 


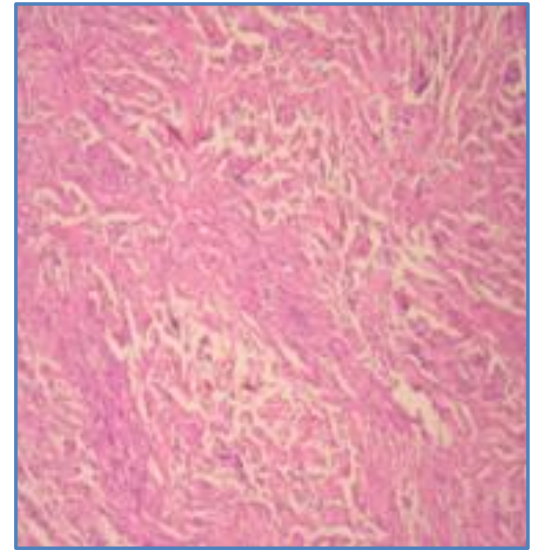

Fig. 7: 10X

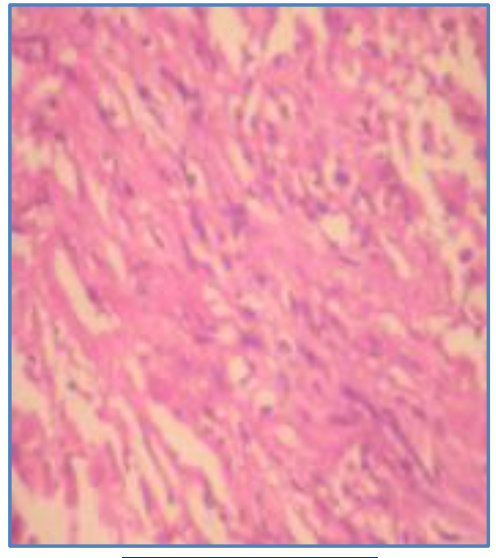

Fig. 8: 20X

Spindle shaped smooth muscle cells and vascular channels lined by endothelial cells.

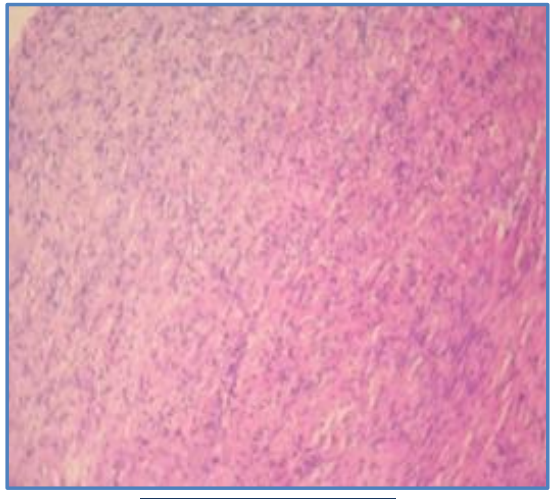

Fig. 9: $10 \mathrm{X}$

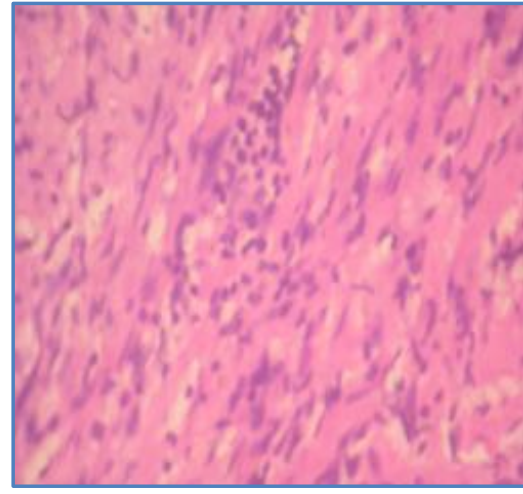

Fig. 10: 20X

Tumor is interspersed by lymphocytes. 


\section{AUTHORS:}

1. D. Prem Charles

2. Divvya B.

3. Rehana Tippoo

4. P. Viswanathan

5. Gopikrishna

\section{PARTICULARS OF CONTRIBUTORS:}

1. $2^{\text {nd }}$ Year Post Graduate, Department of Pathology, Rajah Muthiah Medical College, Annamalai University.

2. $1^{\text {st }}$ Year Post Graduate, Department of Pathology, Rajah Muthiah Medical College, Annamalai University.

3. Professor, Department of Pathology, Rajah Muthiah Medical College, Annamalai University.

4. Professor, Department of Pathology, Rajah Muthiah Medical College, Annamalai University.
5. Assistant Professor, Department of Surgery, Rajah Muthiah Medical College, Annamalai University.

\section{NAME ADDRESS EMAIL ID OF THE CORRESPONDING AUTHOR:}

Dr. P. Viswanathan, Professor, Department of Pathology,

Faculty of Medicine, Rajah Muthiah Medical College, Annamalai University, Chidambaram-608002, Tamilnadu, India.

E-mail:drpviswanathan2013@gmail.com

Date of Submission: 27/03/2014. Date of Peer Review: 28/03/2014.

Date of Acceptance: 21/04/2014.

Date of Publishing: 28/04/2014. 